\title{
Implementasi Augmented Reality pada Museum La Galigo
}

\author{
Syahrir $^{1, a}$, Kurniati Naim ${ }^{2, b}$, Reski Kamil ${ }^{3, c}$ \\ 1,2,3 Jurusan Teknik Elektro, Politeknik Negeri Ujung Pandang, Jl. Perintis Kemerdekaan KM.10, Makassar 90234 \\ a syahrir@poliupg.ac.id \\ bnianaeem09@gmail.com \\ creskikamil@yahoo.co.id
}

\begin{abstract}
Augmented Reality (AR) is known as an interactive technology capable of projecting virtual objects into real objects in real time. The development of $A R$ technology today has contributed a lot of various fields. One of $A R$ implementation in education and entertainment is AR utilization in museum. AR application that tested in this research is AR Mobile. Testing is done by conducting application studies and user studies. Visitors are required to use some of the $A R$ applications provided. Then a visitor's reaction is observed to determine the user's needs. Some methods of this research is the method of tracking the object with the number of markers and the method of tracking objects without markers. This study also discusses other studies on content type, visitors' impression when using AR application. From the results of application testing obtained $93 \%$ of respondents stated that this application is very good and simplify and help visitors. Testing the questionnaire to 30 respondents on the aspect of the Application Process on the Catalog with a Very Good rating $83.35 \%$ and on marker less very good with about $49.95 \%$.
\end{abstract}

Keywords; Augmented Reality, Museum, User Studies, Markeless.

Abstrak-Augmented Reality (AR) dikenal sebagai teknologi interaktif yang mampumemproyeksikan objek maya ke dalam objek nyata secara real time.Perkembangan teknologi AR dewasa ini telah memberikan banyak kontribusike dalam berbagai bidang. Salah satu implementasi AR di bidang edukasi danhiburan yaitu pemanfaatan AR dalam museum. Aplikasi AR yang diujicobakandalam penelitian ini adalah AR Mobile.Pengujian dilakukan dengan melakukan studi aplikasi dan studi pengguna.Pengunjung diminta untuk menggunakan beberapa aplikasi AR yangdisediakan. Kemudian reaksi pengunjung diamati untuk menentukankebutuhan pengguna. Beberapa metode dari penelitian ini yaitu metode pelacakan objek dengan jumlah marker dan metode pelacakan obyek tanpa marker. Penelitian ini juga membahas studi lain mengenai jenis konten,kesan pengunjung saat menggunakan aplikasiAR. Dari hasil pengujian aplikasi didapatkan Sebesar $93 \%$ responden menyatakan bahwa aplikasi ini sangat bagus serta mempermudah dan membantu pengunjung.Pengujian kuesioner kepada 30 responden terhadap aspek Proses Aplikasi pada
Katalog dengan penilaian Sangat Bagus $83.35 \%$ dan pada markerless sangat bagus $\mathbf{4 9 . 9 5 \%}$.

Kata Kunci; Augmented Reality, Museum, Studi Pengguna, Markeless.

\section{Pendahuluan}

Saat ini banyak objek wisata dimakassar yang bermunculan di berbagai tempat, misalnya Pantai Losari, Pantai Tanjung Bira, Bantimurung, Trans Studio Makassar, Museum La Galigo, Museum Balla Lompoa, Ke'te Kesu dan Mallino. Namun kebanyakan hanya berupa tempat rekreasi hiburan keluarga yang kurang memberikan nilai pendidikan bagi para pengunjungnya.Dari sebuah hasil survei yang dilakukan Pusat Penelitian Perkembangan Iptek Lembaga Ilmu Pengetahuan Indonesia (LIPI) mengatakan bahwa masyarakat jarang mengunjungi tempat sumber informasi iptek atau warisan budaya [1]. Hanya $2 \%$ dari responden yang sering pergi ke museum, $5 \%$ ke tempat bersejarah, $7 \%$ ke kebun raya, 10\% ke kebun binatang atau akuarium, dan $18 \%$ ke perpustakaan.

Salah satu museum yang terdapat di Provinsi Sulawesi Selatan yaitu Museum La Galigo yang merupakan salah satu objek wisata pendidikan yang terletak di kota Makassar. Museum ini memiliki koleksi prasejarah, numismatik, keramik asing, sejarah, naskah, dan etnografi. Meskipun memiliki banyak peninggalanpeninggalan sejarah, namun banyak orang masih tidak sadar bertapa pentingnya untuk mengunjungi dan mendapatkan pengetahuan dari museum tersebut karena menganggap kurang menarik untuk ditujukan sebagai tujuan wisata. Berdasarkan wawancara yang kami lakukan pada beberapa orang bahwa alasan mereka jarang mengunjungi museum tersebut tidak begitu menarik, suasananya menyeramkan, isinya 
membosankan dan sederet alasan lain untuk tidak datang ke museum La Galigo.

Untuk mengatasi keadaan yang demikian, maka perlu diadakan usaha-usaha penyampaian informasi dan dokumentasi yang dikemas dengan menarikSehingga rasa keingintahuan masyarakat tentang museum, khususnya Museum La Galigo akanbertambah serta pandangan masyarakat tentang museum akan berubah. Atas dasar inilah muncul ide untuk memanfaatkan teknologi augmented reality dengan memberikan sebuah solusi berupa fasilitas yang memadukan teknologi dengan pengetahuan berupa penyajian informasi [2], [3]. Fasilitas tersebut berupa aplikasi mobile Museum La Galigo berbasis platform Android menggunakan augmented reality. Aplikasi tersebut diharapkan mampu memberikan pengalaman baru bagi masyarakat sebagai media pembelajaran yang lebih menarik dan inovatif.Aplikasi ini juga diharapkan dapat mempermudah masyarakat untuk lebih mengenali museum dan mendapatkan beberapa informasi dari objek-objek di dalamnya dengan aplikasi berbasis 3D.

Banyak penelitian sebelumnya yang terkait dengan penelitian ini seperti pada penelitian [4] yang berjudul Menerapkan Aplikasi Augmented Reality pada ObyekObyek Museum Radya Pustaka. Menyampaikan bahwa manfaat menggunakan teknologi AR dalam pengenalan benda koleksi museum Radya Pustaka sangat besar dan efektif dalam menggugah minat masyarakat untuk mengenal sejarah. Kemudian penelitiannya berjudul Aplikasi Augmented Reality untuk Panduan Museum Berbasis Android Menggunakan Frame Marker. Kemudian dalam penelitian [5] menyampaikan bahwa aplikasi yang dibuat digunakan untuk memudahkan pengunjung dalam memeroleh informasi mengenai museum secara interaktif dan menarik dengan harapan meningkatkan minat masyarakat dalam mengunjungi museum. Kemudian pada penelitian [6] dalam penelitiannya yang berjudul "Pengembangan Museum Virtual Interaktif Menggunakan Teknologi Desktop Virtual Reality Pada Museum Ranggawarsita". Menyampaikan bahwa dengan menggunakan museum virtual $3 D$ sebagai media alternatif yang digunakan untuk membuat museum ranggawarsita menjadi lebih atraktif, menarik minat, serta memperkenalkan kepada wisatawan sebagai tempat wisata yang potensial.

Dari penelitian yang sudah dilakukan tersebut belum dilakukan perbandingan antara deteksi obyek AR dengan marker dan tanpa marker oleh karena itu penelitian ini akan menganalisa perbandingan marker obyek dan markerless obyek 3D atau scan 3D obyek.

\section{Metode Penelitian}

\section{A. Teknik Pengumpulan Data}

Adapun teknik pengumpulan data yang akan dilakukan adalah:

1. Observasi Langsung adalah pengamatan dilakukan untuk memperjelas dan melengkapi data yang diperoleh. Mendapatkan informasi data langsung pada museum La Galigo.

2. Studi Pustaka adalah membaca referensi, buku website dan jurnal penelitian-penelitian sebelumnya yang membahas tentang Augmented Reality.

\section{B. Prosedur Perancangan}

Prosedur perancangan diperlukan agar penelitian dapat terstruktur sehingga hasil yang diperoleh sesuai dengan tujuan penelitian. Aplikasi yang akan dibuat adalah Aplikasi Augmented Reality pada museum La Galigo yang merupakan aplikasi yang diimplementasikan pada platform Android untuk membantu masyarakat lebih tahu tentang Museum La Galigo.

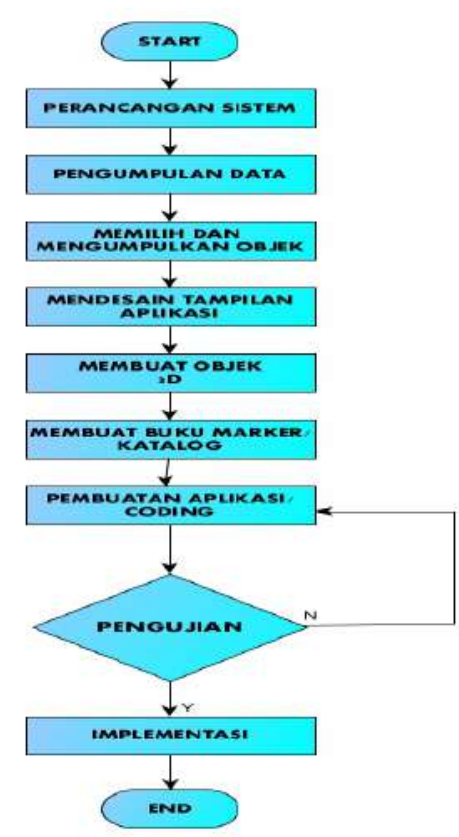

Gambar 1. Diagram Alir Penelitian

\section{Gambaran Umum Aplikasi}

Gambaran umum sistem dari Aplikasi Augmented Reality Museum La Galigo merupakan alur secara keseluruhan dari proses kerja aplikasi ini. Proses interaksi antara software dan user dapat memberikan bentuk proses secara jelas yang terjadi pada aplikasi 
seperti input dan output dari proses yang dikerjakan. Gambaran umum aplikasi yang dirancang diharapkan membuat useraplikasi dapat dengan mudah mengerti dan menggunakan aplikasi.

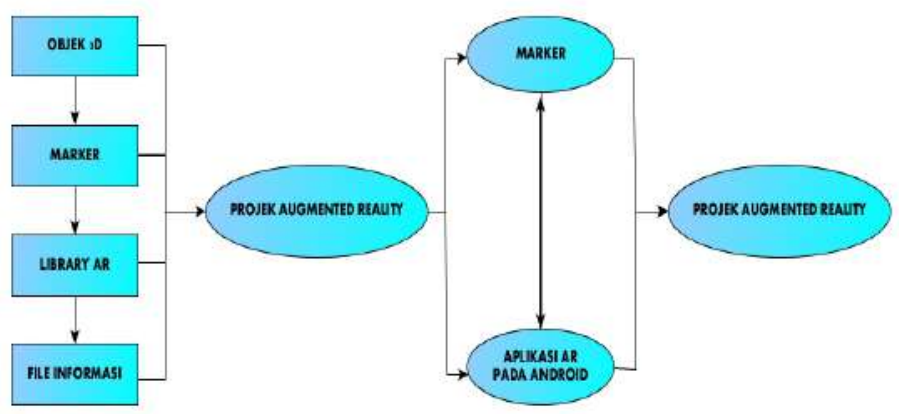

Gambar 2. Gambaran Umum Perancangan Aplikasi Augmented Reality Museum La Galigo

Gambar 2 menjelaskan alur dari pembuatan aplikasi yang akan dibuat. Langkah pertama yaitu membuat objek 3D dari benda yang ada di Museum La Galigo, menyiapkan file informasi untuk setiap benda yang dijadikan 3D, pencarian dan pembuatan gambar sehingga menjadi library marker. Data tahap awal digabungkan menjadi komponen utama projek aplikasi Augmented Reailty Museum La Galigo. Projek augmented reality menghasilkan aplikasi yang mampu digunakan pada platform Android yang mampu digunakan langsung untuk mendeteksi marker, sehingga menghasilkan output berupa objek 3D dan informasi dari benda tersebut.

\section{Diagram Activity Penggunaan Aplikasi}

Diagram activity penggunaan aplikasi menggambarkan alur aktivitas yang terjadi dalam aplikasi Augmented Reality pada Museum La Galigo.

Gambar 3 menunjukkan secara umum alur kerja aplikasi Augmented Reality pada Museum La Galigo.User menggunakan smartphone berbasis Android yang sudah ter-install aplikasi Augemented Reality pada Museum La Galigo. Tampilan splash screen muncul setelah user membuka aplikasi.Sistem selanjutnya menampilkan menu utama dari aplikasi.Menu utama memiliki pilihan gedung yang bisa user pilih. User harus memilih salah satu gedung yang ingin dideteksi. Tampilan informasi gedung muncul setelah user memilih gedung yang diinginkan. Informasi gedung merupakan gambaran umum mengenai gedung yang dipilih. Sistem kemudian membawa user ke tampilan utama kamera untuk mendeteksi marker.

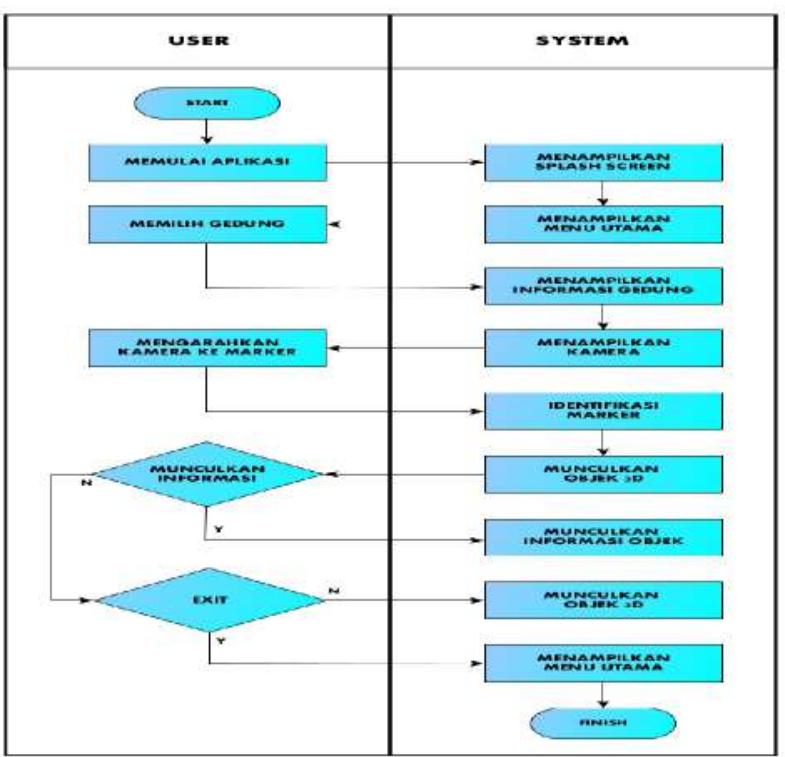

Gambar 3. Diagram Activity Aplikasi Augmented Reality Pada Museum La Galigo

Sistem bekerja dengan mendeteksi objek yang dijadikan sebagai marker dan buku marker khusus yang sudah disediakan. Kamera diarahkan user pada ketinggian tertentu guna mendapatkan hasil deteksi yang maksimal.Sistem hanya memunculkan objek 3D sesuai dengan marker dari gedung yang dipilih. Satu marker mewakili satu benda yang terdapat di Museum yang sudah dibuat dalam bentuk 3D. Informasi mengenai objek 3D yang dimunculkan terdapat dalam bentuk tulisan dan suara.User dapat kembali ke menu utama sebelum benar-benar keluar dari aplikasi.

\section{Use Case Diagram}

Use Case Diagram digunakan untuk menggambarkan requirement fungsional dari aplikasiAugmented Reality Museum La Galigo serta bagaimana aplikasi ini berinteraksi dengan user seperti gambar berikut.

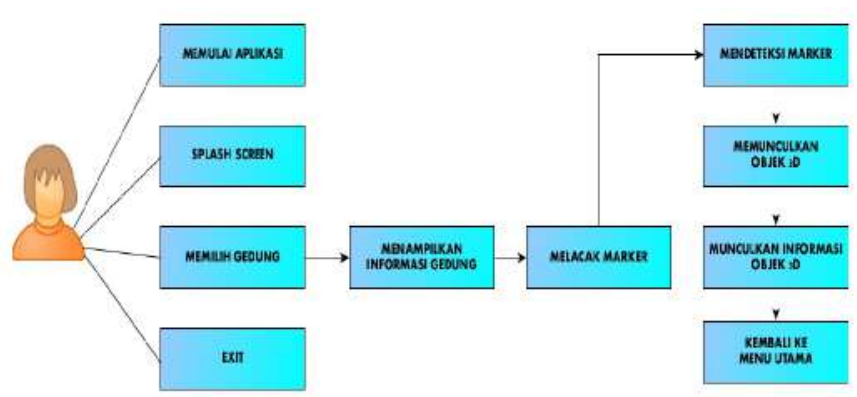

Gambar 4. Use Case Diagram Aplikasi Augmented Reality Museum La Galigo 
Gambar 4 menunjukkan fitur-fitur utama yang terdapat pada aplikasi Augmented Reality pada Museum La Galigo. User dapat langsung memulai melacak marker dengan memilih gedung mana yang diinginkan.Objek 3D langsung muncul setelah kamera dengan tepat berada di posisi yang diinginkan marker. User tidak perlu keluar dari kamera bila ingin mendeteksi marker yang baru. User bisa keluar dari aplikasi dengan memilih kembali ke menu utama terlebih dahulu.

\section{Hasil dan Pembahasan}

Hasil penelitian ini berupa aplikasi media informasi untuk mengetahuisejarah dan benda-benda peninggalan sejarah yang disimpan pada Museum LaGaligo. Aplikasi ini sudah dirancang berbasis android serta objek yang dirancangberbentuk 3D hampir mirip dengan bentuk aslinya dan dilengkapi dengan fasilitas deskripsi suara yang diaktifasi secara otomatis agar para wisatawan lebihmudah untuk menggunakan aplikasi ini.

\section{A. Hasil}

Adapun hasil tampilan antarmuka pada aplikasi dapat dilihat pada gambar di bawah ini :

\section{Tampilan Splash Screen dan Loading}

Pada saat aplikasi dimulai akan diawali dengan menampilkan splash screen. Tampilan splashscreen ini dibuat untuk menunjukkan logo dari kampus.Selanjutnya akan diikuti oleh tampilan prose loading aplikasi yang sedang berjalan sebelum aplikasi ini siap digunakan.

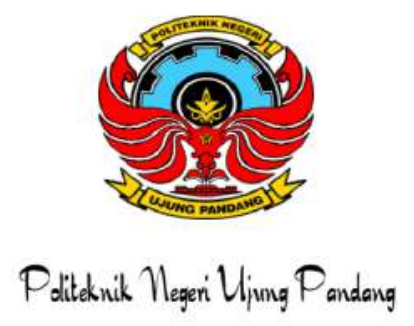

Gambar 5. Splash screen Augmented Reality Museum La Galigo

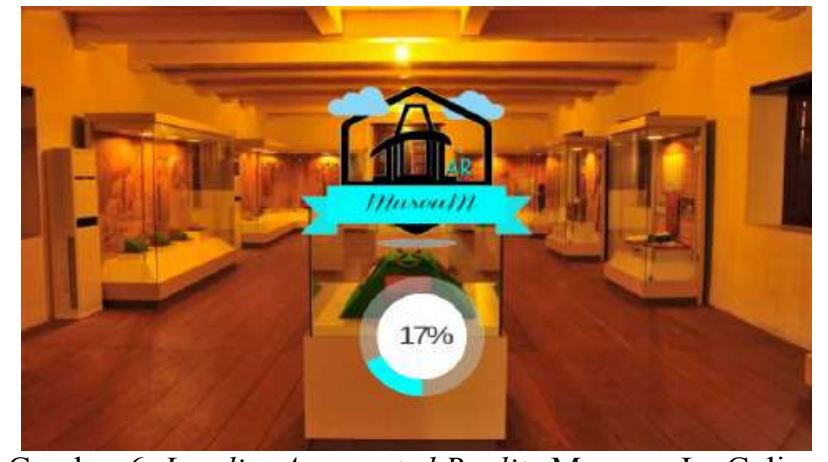

Gambar 6. LoadingAugmented Reality Museum La Galigo

\section{Interface Menu Utama Aplikasi}

Tampilan utama aplikasi ini merupakan tampilan aplikasi yang sudah siap digunakan.

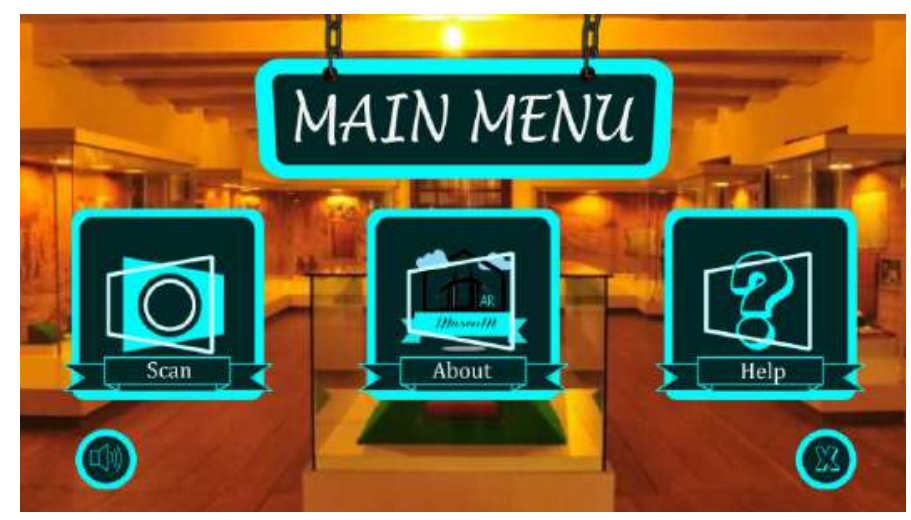

Gambar 7. Interface Menu Utama Aplikasi

Pada tampilan utama ini terdapat 5 menu tombol yaitu tombol scan,tombol about, tombol help, tombol sounds dan tombol keluar.

\section{Interface Menu Scan}

Pada saat kamera smartphone diarahkan pada marker/halaman yangterdapat pada buku Marker Museum akan menampilkan objek 3D serta tombol-tombol navigasi yang terdapat pada layar smartphone. 


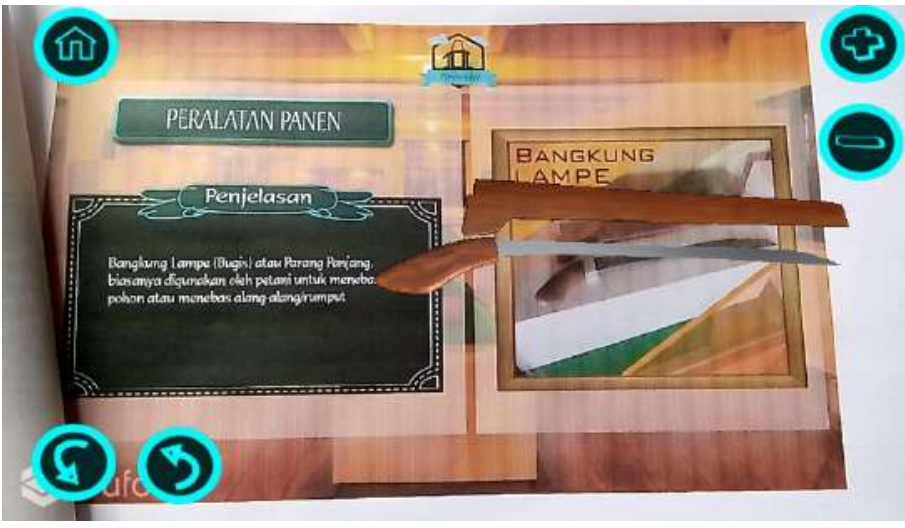

Gambar 8. Tampilan Proses Scan objek 3D pada Katalog

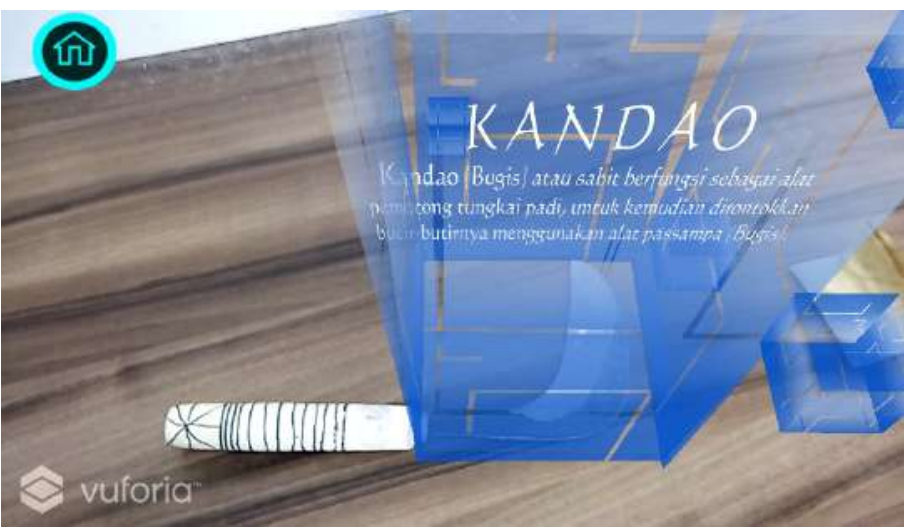

Gambar 9. Tampilan Proses Scan objek 3D pada Sabit

4. Interface Menu About

Tampilan ini menampilkan nama si pembuat aplikasi ini.

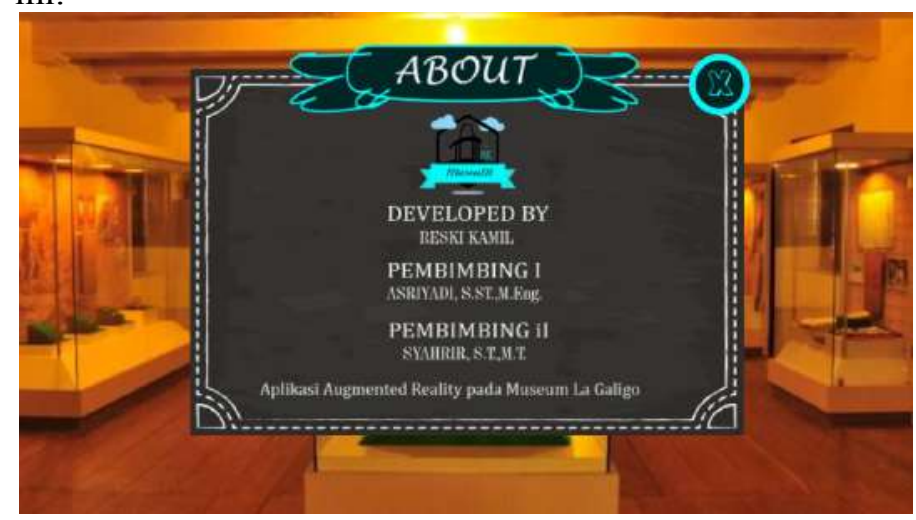

Gambar 10. Tampilan Developer Aplikasi

5. Interface Menu Help

Pada tampilan ini dapat dilihat cara penggunaan aplikasi secara sederhana lengkap.

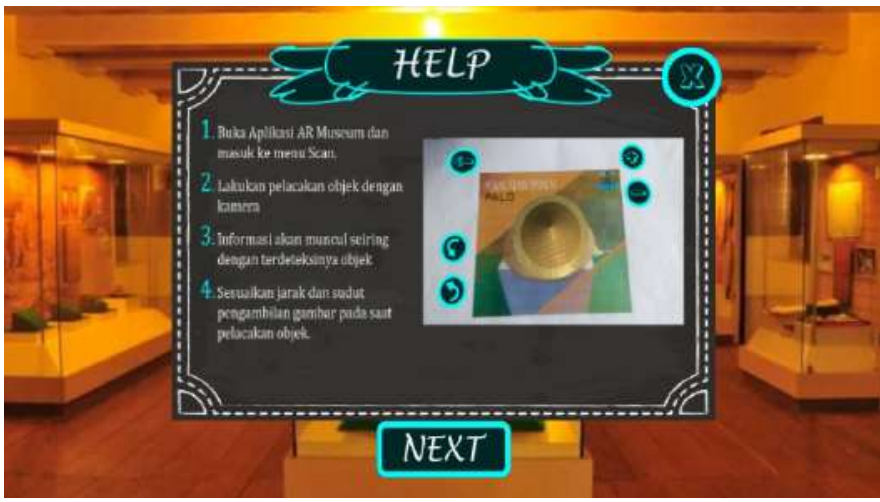

Gambar 11. Tampilan Bantuan menggunakan Aplikasi

Dan adapun hasil tampilan sampul buku marker aplikasi dapat dilihat pada gambar di bawah ini :

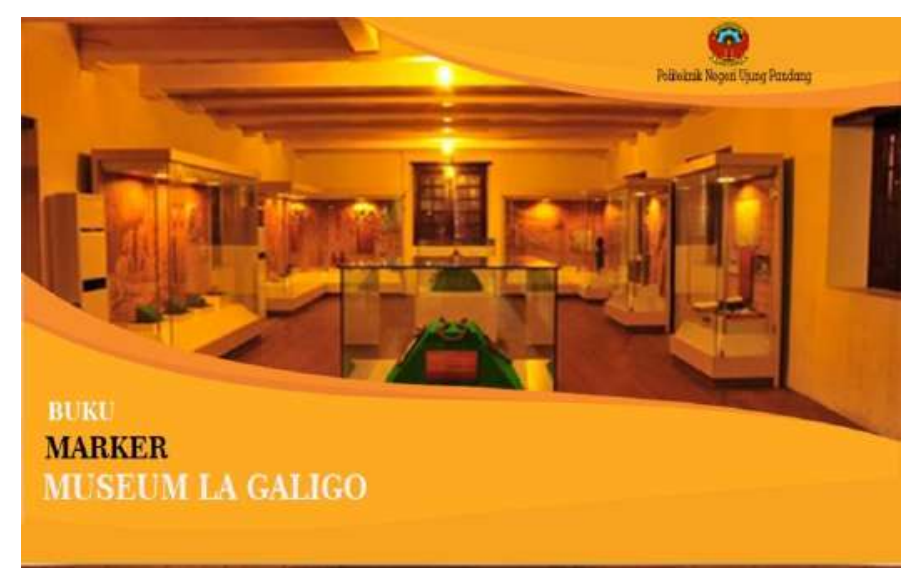

Gambar 12. Sampul Buku Marker untuk Aplikasi Augmented Reality Museum La Galigo.

\section{B. Pengujian Aplikasi}

1. Pengujian Aplikasi pada Beberapa Smartphone

Uji coba aplikasi pada beberapa smartphoneakan dilakukan pada 2 macam smartphone yang memiliki jenis processor yang berbeda yaitu smartphone dengan processor ARMV7 seperti Samsung Galaxi Mega dan Oppo Neo 5.

Tabel 1. Perbandingan pengujian beberapa smartphone

\begin{tabular}{|l|l|l|}
\hline $\begin{array}{l}\text { Ruang lingkup } \\
\text { pengujian }\end{array}$ & $\begin{array}{l}\text { Samsung Galaxi } \\
\text { Mega }\end{array}$ & Oppo Neo 5 \\
\hline OS & Android 2.2 & Android 4.0 \\
\hline Tipe Prosessor & $\begin{array}{l}1.7 \mathrm{GHz} \text { Dual- Core } \\
\text { (ARMV7) }\end{array}$ & $\begin{array}{l}1.3 \mathrm{GHz} \text { Quad- } \\
\text { Core (ARMV7) }\end{array}$ \\
\hline
\end{tabular}




\begin{tabular}{|l|l|l|}
\hline $\begin{array}{l}\text { Rata-rata lamanya } \\
\text { pendeteksian marker }\end{array}$ & 1.9 detik & 1.7 detik \\
\hline $\begin{array}{l}\text { Rata-rata lamanya } \\
\text { pendeteksian } \\
\text { markerless }\end{array}$ & 4.5 detik & 6.3 detik \\
\hline Resolusi Kamera & $8 \mathrm{MP}$ & $8 \mathrm{MP}$ \\
\hline
\end{tabular}

\section{Pengujian Hasil oleh User (Kuisioner)}

Pengujian ini dilakukan untuk melihat pendapat dan respon pengguna terhadap aplikasi Augmented Reality padaMuseum La Galigo. Kuesioner dibagikan kepada 30 responden. Terdapat 3 Aspek yang diujikan untuk catalog dan Markeless padakuesioner pengguna yaitu Aspek Proses Aplikasi pada Katalog dan Markeless, Aspek Deteksi Waktu pada Katalog dan Markeless dan Aspek Desain User Interface pada Katalog dan Markeless. Berikut merupakan keempataspek tersebut.

\section{Aspek Proses Aplikasi pada Katalog dan Markeless}

Berikut ini Gambar 13 merupakan persentase dari pengujian kuesioner kepada 30 responden terhadap aspek Proses Aplikasi pada Katalog dengan penilaian Sangat Bagus $83.35 \%$.

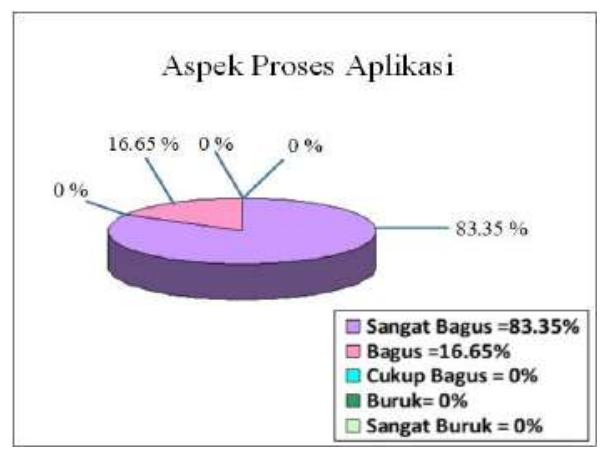

Gambar 13. Persentase Penilaian Aspek Proses Aplikasi pada Katalog.

Berikut ini Gambar 14 merupakan persentase dari pengujian kuesioner kepada 30 responden terhadap aspek Proses Aplikasi pada Markeless dengan penilaian Sangat Bagus 49.95\%.

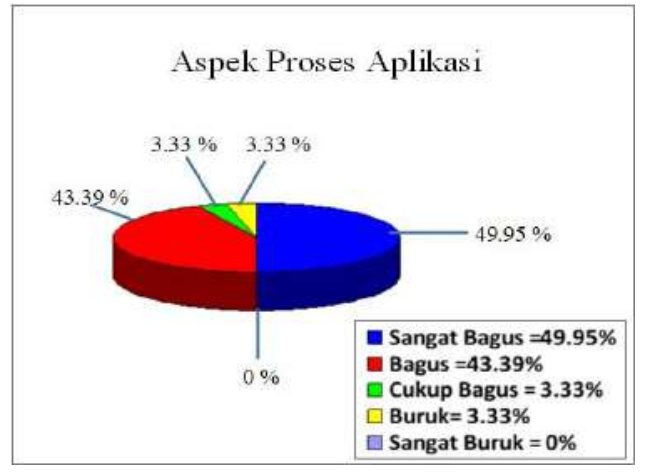

Gambar 14. Persentase Penilaian Aspek Proses Aplikasi pada Markeless.

\section{AspekDeteksi Waktu}

Berikut ini Gambar 15 merupakan persentase dari pengujian kuesioner kepada 30 responden terhadap aspek Deteksi Waktu pada Katalog dengan penilaian Sangat Bagus 63.37\%.

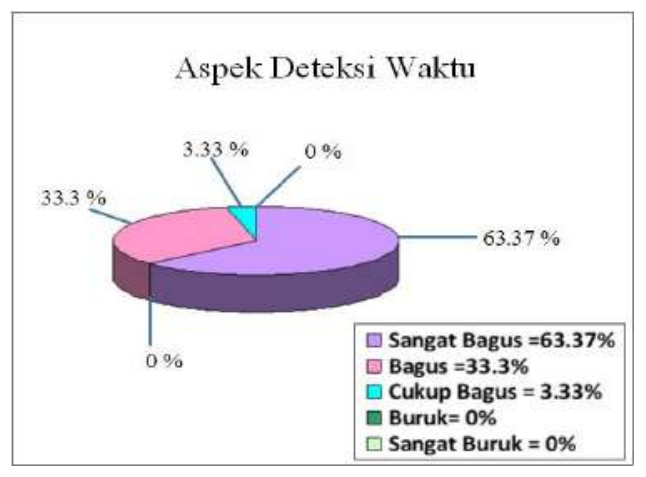

Gambar 15. Persentase Penilaian Aspek Deteksi Waktu pada Katalog.

Berikut ini Gambar 16 merupakan persentase dari pengujian kuesioner kepada 30 responden terhadap aspek Deteksi Waktupada Markeless dengan penilaian Bagus $46.72 \%$.

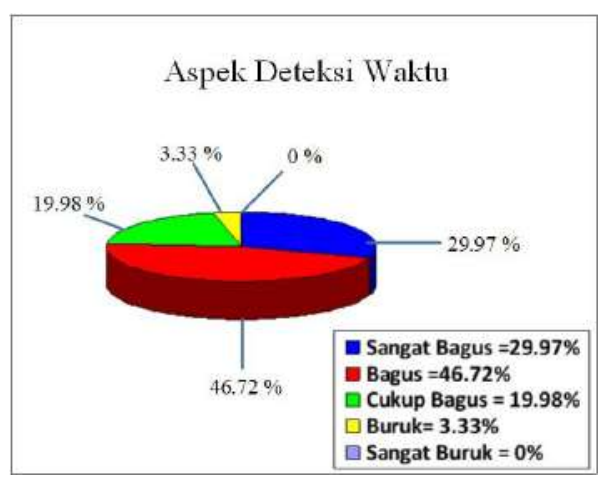

Gambar 16. Persentase Penilaian Aspek Deteksi Waktu pada Markeless. 
3. Aspek Desain User Interface

Berikut ini Gambar 17 merupakan persentase dari pengujian kuesioner kepada 30 responden terhadap aspek Desain User Interface pada Katalog dengan penilaian Sangat Bagus 50.5\%.

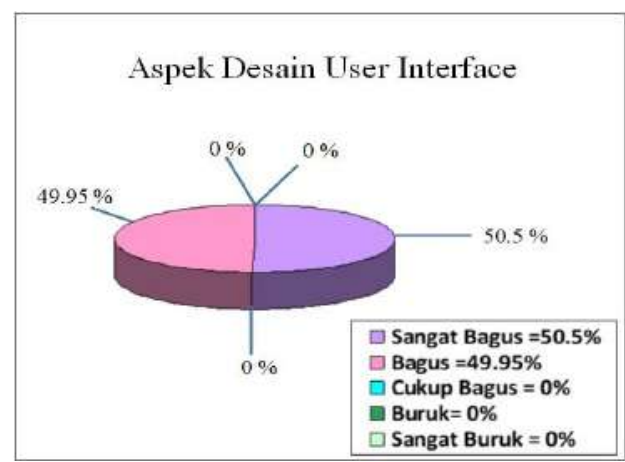

Gambar 17. Persentase Penilaian Desain User Interface pada Katalog.

Berikut ini Gambar 18 merupakan persentase dari pengujian kuesioner kepada 30 responden terhadap aspek Desain User Interfacepada Markeless dengan penilaian Bagus 4 6.62\%.

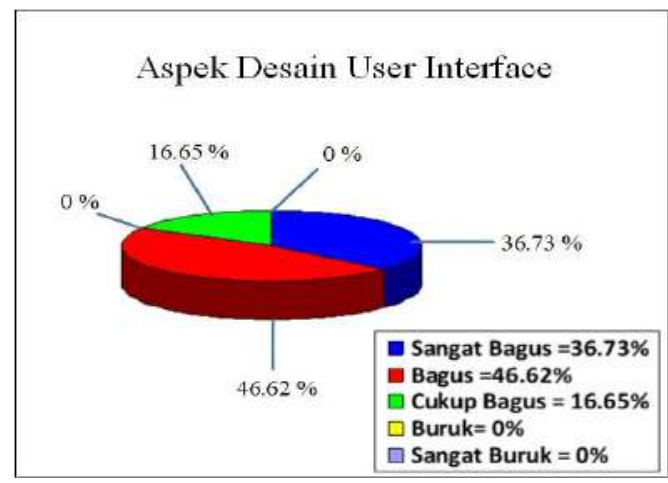

Gambar 18. Persentase Penilaian Desain User Interface pada Markeless.

\section{Pengujian Skala Likert untuk Keseluruhan Aplikasi}

Berikut ini Gambar 19 merupakan persentase dari pengujian kuesioner kepada 30 responden terhadap aspek Proses Aplikasi Secara Keseluruhan dengan penilaian Sangat Bagus 66.6\%.

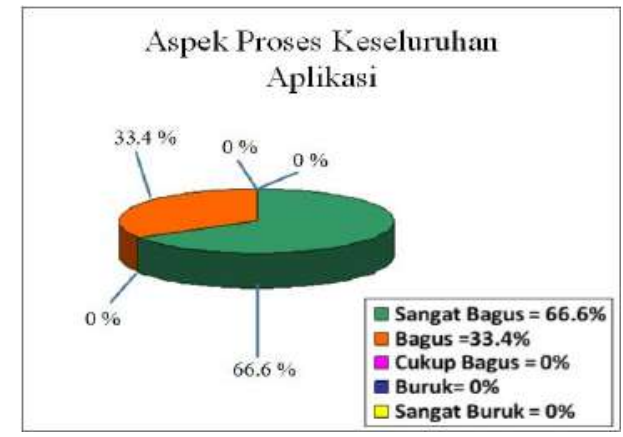

Gambar 19. Persentase Penilaian Aspek Proses Aplikasi Secara Keseluruhan

Tabel 2. Tabel Hasil Pengujian Skala Likert

\begin{tabular}{|c|c|c|}
\hline \multirow{2}{*}{$\mathbf{R}$} & Aspek & \multirow[t]{2}{*}{ Tot. } \\
\hline & 1 & \\
\hline 1 & 5 & 5 \\
\hline 2 & 4 & 4 \\
\hline 3 & 4 & 4 \\
\hline 4 & 5 & 5 \\
\hline 5 & 5 & 5 \\
\hline 6 & 5 & 5 \\
\hline 7 & 4 & 4 \\
\hline 8 & 5 & 5 \\
\hline$\ldots$ & . & . \\
\hline 28 & 4 & 4 \\
\hline 29 & 4 & 4 \\
\hline 30 & 5 & 5 \\
\hline & Jumlah & 140 \\
\hline
\end{tabular}

Jumlah skor ideal untuk pertanyaan yang diajukan kepada responden :

a) Skor tertinggi (Y) : 5 x 30 $=150$ (Sangat Bagus)

b) Skor tertinggi $(\mathrm{X}): 1$ x $30=30$ (Sangat Buruk)

Interprestasi skor hasil pengamatan :

$$
\begin{aligned}
& \operatorname{Index}(\%)=(\text { Total skor/Y }) \times 100 \\
& \operatorname{Index}(\%)=(140 / 150) \times 100 \\
& \operatorname{Index}(\%)=93,3 \%
\end{aligned}
$$

Dari hasil pengujian aplikasi oleh 30 pengguna didapat hasil sebesar $\mathbf{9 3 , 3 \%}$ yang diinterpretasikan maka dapat disimpulkan bahwa penilaianyang dilakukan responden/pengguna aplikasi terhadapkeseluruhan aplikasi dinilai Sangat Bagus. 


\section{E. Analisis Hasil Pengujian Aplikasi}

Berikut ini adalah analisis hasil perancangan dan pengujian aplikasi Augmented Reality pada Museum La Galigo.

1. Berdasarkan tabel 1 pengujian di atas dapat dilihat bahwa smartphone yang mempunyai jenis prosessor ARM v7 lebih cepat mendeteksi marker dan objek yang muncul lebih stabil.

2. Dari hasil analisis terhadap pengujian kuesioner pengguna aplikasi oleh 30 responden penilaian aplikasi Augmented Reality Museum ini berada dalam kategoriSangat Bagus. Hal ini berdasarkan perhitungan menggunakan Skala Likert dengan nilai $\mathbf{9 3 , 3 \%}$ yang diinterpretasikan maka dapat disimpulkan bahwa keseluruhan aplikasi dinilai Sangat Bagus.

\section{Kesimpulan}

Berdasarkan pengujian dan hasil analisis ImplementasiAplikasi Augmented Reality pada Museum La Galigo, maka dapatdisimpulkan bahwa:

1. Pendeteksian Marker dan Markeless pada aplikasi telah berjalan dengan baik. Objek 3D benda-benda Museum dapat muncul dengan baik pada Katalog dan Markerless tersebut.

2. Dari pengujian yang dilakukan aplikasi ini dapat dijalankan pada smartphone yang memiliki processor dengan arsitektur ARMv7 karena kapasitas prosesornya lebih besar dari arsitektur ARMv6.

3. Sebesar $93 \%$ responden menyatakan bahwa aplikasi ini sangat bagus serta mempermudah dan membantu pengunjung.
4. Dalam penggunaan aplikasi harusdiperhatikan jarak dan focus kamera dengan marker serta terdapat cahaya yang cukup terang.Semakin dekat jaraknya semakinbaik mendeteksi marker namunsemakin jauh akan mengganggu performa aplikasi.

\section{Ucapan Terima Kasih}

Ucapan terima kasih diberikan kepada Kementerian Riset dan Teknologi DIKTI yang telah membiayai penelitian ini dan juga kepada Politeknik Negeri Ujung Pandang Jurusan Teknik Elektro Program Studi Teknik Multimedia dan Jaringan yang telah memberikan fasilitas laboratorium untuk pengujian aplikasi.

\section{Daftar Pustaka}

[1] Auliawati B, Steven R,Sentinuwo, Stanley D.S.K."Implementasi Augmented Reality warisan Budaya Berwujud di Museum Propinsi Sulawesi Utara". EE-journal Teknik Informatika, Volume 6, No. 1, ISSN : 2301-8364.2015

[2] Nahlah, Amiruddin, Farida A., "Perancangan Website Sekolah Pada SDN 103 kabupaten Sinjai Sebagai Salah Satu Sarana Pembelajaran Online dan Penvaiian Informasi”.,Journal INTEK, Vol 4, No. 2.,Hal.92-99.,E-ISSN 2615-5427

[3] Hardiansyah, Fadillah F., Yuliana S., Kholid F., "Augmented Reality Untuk Mengetahui Fasilitas Umum Berbasis Android"., Naskah Publikasi. Surabaya: Institut Teknologi Sepuluh Nopember. 2012

[4] Prasetya, D. A., Muhammad Nurruzzaman., "Menerapkan Aplikasi AugmentedReality pada Obyek-Obyek Museum Radya Pustaka"., Simposium Nasional Teknologi Terapan., Surakarta:. Universitas Muhammadiyah Surakarta. 2013.

[5] Chandra, Robert., Jessica., Kristama., "Aplikasi Augmented Reality UntukPanduan Museum Berbasis Android Menggunakan Frame Marker"., Naskah Publikasi. Jakarta: Universitas Bina Nusantara. 2012

[6] Servasius V., "Pengembangan Museum Virtual Interaktif Menggunakan Teknologi Desktop Virtual Reality Pada Museum Ranggawarsita".,2015 